E3S Web of Conferences 1, 19010 (2013)

DOI: $10.1051 / \mathrm{e} 3$ sconf/20130119010

(c) Owned by the authors, published by EDP Sciences, 2013

\title{
Assessment of the Distribution of Heavy Metals around a Cu Smelter Town, Karabash, South Urals, Russia
}

\author{
Y. G. Tatsy \\ Vernadsky Institute of Geochemistry and Analytical Chemistry of the Russian Academy of Science, \\ 19 Kosygin St., Moscow 119991, RUSSIA, tatsy@geokhi.ru
}

\begin{abstract}
Technogenic geochemical anomaly was formed as a result of large-scale copper-smelting production run for almost hundred years without any ecological standards in Karabash region. Environmental assessment of the area affected by the $\mathrm{Cu}$ smelter plant after the plant's substantial modernization shows that atmospheric emissions remain sufficiently high, and re-vegetation that began emerging during the time the plant was closed has slowed down after the plant reopened. The assessment of contamination of soil, bottom sediments and surface water showed extremely high concentrations of heavy metals.
\end{abstract}

Key words: Heavy metals, Karabash, soil and water pollution

\section{Introduction}

Local technogenic anomalies are formed in in the area of mining and metallurgical enterprises. Such cites can be seen as natural-technogenic testing areas for studying processes of involvement of chemicals in natural migratory flows. The Karabash technogenic anomaly which was being formed around the large copper smelter plant is precisely such testing area and gives a unique opportunity to study the degradation and restoration of the environment under changing technogenic load.

During its existence the Karabash $\mathrm{Cu}$ smelter plant emitted more than 10 million tones of toxic substances SO2, dust, heavy metals into the atmosphere. In 1989 the smelter plant was stopped and in 1995 the Ministry of natural resources and environment of Russian Federation recognized Karabash as territory of environmental disaster. In 1998 the plant was started up again and currently it intensively upgraded. However, the area continues to suffer, although to a lesser extent, from wastewater, gas and dust emissions, as well as acidic drains from abandoned mines.

The main goal of this work is to assess and characterize distribution (the fallout spots) of HM and arsenic around the Karabash $\mathrm{Cu}$ smelter plant after its modernization.

\section{Materials and Methods}

Field work was carried out in the 2010-2011 around the town of Karabash, Chelyabinsk region, South Ural, Russia. The smelter is located close to the town centre and produces blister copper and sulfuric acid.

Karabash lies within the SW-NE trending flat bottomed valley with altitudes ranging from 250 to 650 $\mathrm{m}$. The dominance of $\mathrm{W}, \mathrm{SW}$ and $\mathrm{NW}$ wind directions creates a complex picture of the distribution of aerial industrial emissions, and in the windless weather leading to sedimentation on the urban territory. This is caused by the fact that the valley is limited by the high mountain range from the east, which controls the circulation of air masses and creates inversion $(\mathrm{smog})$ situations in it.

Top soil samples were collected by scooping the abundant material directly into a polyethylene bag, using a steel shovel. All samples were air dried and homogenized using a sieve with a $2-\mathrm{mm}$ cell.

Lake sediment core was taken from the deepest part of Lake Serebry by sediment corer. The core was sliced into $1 \mathrm{~cm}$ intervals in the field and stored in polythene bags in refrigerator at $4^{\circ} \mathrm{C}$.

Water samples were collected into a $100 \mathrm{ml}$ acidwashed Nalgene bottle from the water surface and were filtered in the field.

Chemical analysis was performed in Vernadsky Institute of Geochemistry and Analytical Chemistry RAS by different methods - AES, GFAAS, ICP-MS and CVAAS $(\mathrm{Hg})$.

\section{Results and Discussion}




\section{Atmosphere}

Results of analyses performed in the fall of 2000, showed extremely high levels of $\mathrm{SO}_{2}$ and dust particles in the air (Udachin et al., 2003). Concentrations of $\mathrm{SO}_{2}$ up to $20000 \mathrm{mg} / \mathrm{m}^{3}$ were recorded at a distance about $1 \mathrm{~km}$ of stack directly under the torch. It is many times greater than MPC (maximum permissible concentration) even for working area $\left(10 \mu \mathrm{g} / \mathrm{m}^{3}\right)$. Oxidation of $\mathrm{SO}_{2}$ to $\mathrm{SO}_{3}$ and dissolution in atmospheric moisture leads to formation of sulfuric acid, which as "acid rains" had a negative impact on soil and vegetation.

The modernization of the smelter company aimed at changing technology has led to a significant reduction of emissions into the atmosphere. According to official reports, emissions declined for main pollutants - for sulphur dioxide in more than 4 times and for inorganic dust more than 10 times (Fig. 1), as well as for $\mathrm{Pb}-10$, $\mathrm{Cu}-30$, As - 50, and $\mathrm{Zn}-70$ times.

It should be noted that in Canada, where the main source of emissions of sulphur dioxide are non-ferrous metallurgy, in 1990, emissions of entire Canada were 3259 , in $2000-2379 \mathrm{t}$, and according to the forecast on $2010-2244 \mathrm{t}$ of $\mathrm{SO}_{2}$ (Niemi, 2005), which is several times less than from Karabash $\mathrm{Cu}$ smelter, despite significant reductions of emissions in recent years.

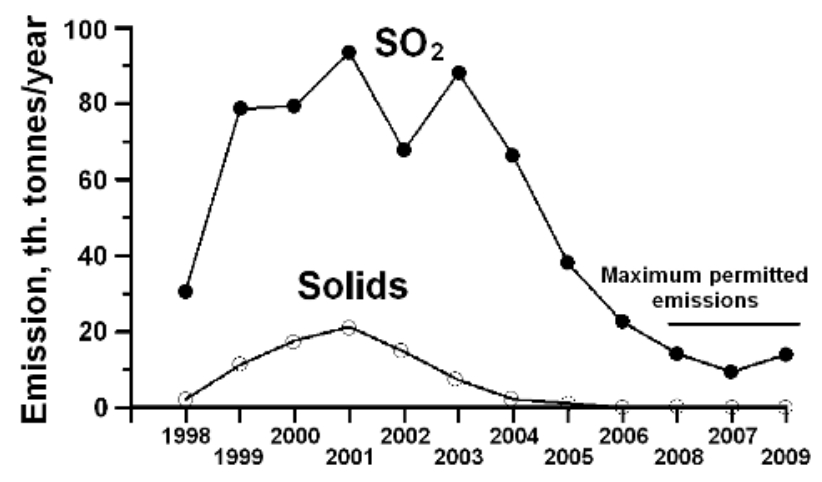

Fig. 1. Dynamics of emissions of $\mathrm{SO}_{2}$ and solids from Karabash $\mathrm{Cu}$ smelter

Analysis of the data shows that as before the renovation the most dangerous are the emissions of sulphur dioxide $\left(\mathrm{SO}_{2}\right)$, which accounts for $76 \%$ of total emissions, and dust (19.2\%). Williamson et al. (2004) showed that a large proportion (up to $99 \%$ ) of particles in emissions of Karabash smelter have a size $<3 \mu \mathrm{m}$, i.e. in the range of PM10. Numerous studies (see, for example, Richards, 1997) revealed the adverse impact of PM10 to health. It is believed that this was largely due to the ability of smaller particles penetrate into the deepest field of lungs, and due to increased surface area to increase solubility and possibility of surface reactions.

\section{Soils and Vegetation}

In the territory being investigated predominately the gray forest soils, which it is characterized by the well expressed differentiation of profile, low content of organic carbon in the humus-accumulative horizons, and weakly shifted in acid $\mathrm{pH}$ range of organic horizons. In the impact zone under the effect of acid atmospheric precipitations and large numbers of semyoxygenized sulfur compounds occurs the acidification of the upper levels of soils ( $\mathrm{pH}$ does not exceed 4.2). The entering flux of HM in largely is determined by dust component of metallurgical process. As a result anomalous soils with the typical technogenic-accumulative distribution of elements are formed.

Complex ecological situation in the region it is created by more than 100-year-old activity of Karabash smelter, during which preconditions were created for development of active degradation processes - soil erosion and disappearance of vegetation. As a result two natural- technogenic zones were formed around the smelter: impact and buffer, identified based on the degree of the degradation of natural vegetation and soils.

In impact (decertified) zone the action of emissions and deforestation destroyed the basic mechanism to ensure the sustainability of the soil cover and increased development on the slopes of planar and linear erosion. This zone is characterized by the absence of natural vegetation, soil cover and the highest levels of heavy metal contamination. The center of zone is technogenic barren with area about $10 \mathrm{~km} 2$.

In the buffer zone in the birch groves natural renewal is absent, coniferous species in the significant territories are absent or oppressed, substantially degraded living soil cover - species composition is depleted, ground phytomass is reduced, and inhibition processes of destruction leads to an increase pf litter layer and reduction in biological activity of soils.

Impact of smelter emissions led to the significant accumulation in the preserved soil such elements as As $\mathrm{Cu}, \mathrm{Ni}, \mathrm{Pb}, \mathrm{Zn}, \mathrm{Hg}$, in quantities, which many times exceed Maximum Allowable Concentrations (MAC) (table 1). However, these lands are used for private vegetable gardens and pastures. The total index of pollution $\mathrm{Zc}$ for this zone is $250-500$, which corresponds to the extremely high level of technogenic pollution and extremely dangerous level of sanitary- toxicological hazard.

A good indicator of pollution is the forest litter that can be seen as accumulator of pollutants. An increase in thickness of litter occurs with the approaching to the source of emissions, its gross storage in the buffer zone in more than 4 times higher than that for the background area. Anthropogenic impact reduces the rate of biochemical processes and in the conditions of strong pollution it impedes or completely stops destruction of organic matter in litter. Furthermore, fractional structure of litter is changed and in immediate vicinity of the smelter in its composition there are no traces of living soil cover. 
Table 1. Concentrations of elements in soils and litter, $\mathrm{mg} / \mathrm{kg}$

\begin{tabular}{|c|c|c|c|c|}
\hline \multirow{2}{*}{ Element } & \multirow{2}{*}{$\begin{array}{c}2 \mathrm{~km} \text { to the South } \\
\text { Soil }\end{array}$} & \multicolumn{2}{|c|}{$6 \mathrm{~km}$ to the Nord } & \multirow[t]{2}{*}{ MAC/APC* } \\
\hline & & Soil & Litter & \\
\hline $\mathrm{pH}$ & 3.75 & 3.71 & & \\
\hline $\mathrm{Al}$ & 28730 & 20980 & 3379 & \\
\hline As & 493 & 77.7 & 558 & $2.0 / 5$ \\
\hline $\mathrm{Ba}$ & 1373 & 303 & 563 & \\
\hline $\mathrm{C}$ & 3.1 & 0.5 & & \\
\hline $\mathrm{Cd}$ & 12.7 & 2.8 & 100 & $-/ 1.0$ \\
\hline Co & 51.4 & 15.2 & 7.4 & \\
\hline $\mathrm{Cr}$ & 313 & 48.2 & 12.5 & \\
\hline $\mathrm{Cu}$ & 4340 & 997 & 12165 & $33 / 66$ \\
\hline $\mathrm{Fe}$ & 4750 & 21710 & 25665 & \\
\hline $\mathrm{Hg}$ & 2.3 & 0.9 & 4.5 & $2.0 /-$ \\
\hline $\mathrm{Mg}$ & 26440 & 5763 & 1765 & \\
\hline $\mathrm{Mn}$ & 2426 & 93 & 2517 & $1500 /-$ \\
\hline $\mathrm{Ni}$ & 280 & 30.2 & 42 & $-/ 40$ \\
\hline $\mathrm{Pb}$ & 900 & 339 & 9609 & $32 / 65$ \\
\hline $\mathrm{Pb}+\mathrm{Hg}$ & $900+2.3$ & $339+0.9$ & & $20.0+1.0 /-$ \\
\hline $\mathrm{S}$ & 6278 & 5810 & 6842 & $160 /-$ \\
\hline $\mathrm{Sb}$ & 9.6 & 2.7 & 12.2 & $4.5 /-$ \\
\hline $\mathrm{Se}$ & 5.1 & 1.3 & 12.8 & \\
\hline $\mathrm{Sr}$ & 81.9 & 45.7 & 38.4 & \\
\hline $\mathrm{V}$ & 77.5 & 59.0 & 39.0 & $150 /-$ \\
\hline $\mathrm{Zn}$ & 1877 & 554 & 17215 & $55 / 110$ \\
\hline
\end{tabular}

* MAC/APC - Maximum Allowable Concentration /Approxible Permissible Concentration

\section{Surface Waters}

The bedrock in the Karabash area has a relatively high acid-neutralization potential that ensures the lakes are buffered against acid rain. All the lakes are currently neutral or slightly alkaline. Nevertheless, surface water in the zone of the smelter activity considerably differs from natural and their chemical composition reflects the nature of technogenic pollution. The least polluted Lake Serebry is a source of drinking water. However, the HM contents in the in the upper layer of bottom sediments of this lake exceed background for $\mathrm{Cd}, \mathrm{Pb}, \mathrm{Zn}, \mathrm{Cu}$ and $\mathrm{Hg}$ in 100-400 times (Fig. 2). High buffer capacity limited bioavailability of metals in the water column and sediment.

Waters of Karabashsky and Bogorodsky Ponds are characterized by neutral $\mathrm{pH}$ and high mineralization; they contain high concentrations of sulfates and HM - Zn, Mn, $\mathrm{Cd}$ and $\mathrm{Ni}$, which is typical for waste-waters of metallurgical plants. Nevertheless, the comparison of the obtained results with the data 2005 shows gradual reduction in the chemical pollution of these water bodies. Small Sak-Elga River is intensively contaminated by industrial wastes. The main sources of pollution are the Ryzhiy Creek and pyrite deposits in river flood plain. Before flowing into Sak-Elga River, stream is characterized by the hurricane contents of sulfate ion, chlorine and metals: $\mathrm{Al}-440, \mathrm{Fe}-375, \mathrm{Cu}-58, \mathrm{Zn}-87$,
$\mathrm{Pb}-1.5$, and $\mathrm{Cd}-1.7 \mathrm{mg} / \mathrm{l}$. In the first years of ore mill activity sulfide- silicate ore wastes (tails) were dropped into the Sak-Elga river bed. This immediately led to the appearance of hyper acidic reaction of pore solutions with $\mathrm{pH}$ 2.4-2.7 and the hurricane contents of HM in pore waters, as well as to death of vegetation in river flood plain. Pyrites and other sulfide materials under influence of aeration, atmospheric precipitations, solar radiation, and sulfur dioxide are oxidized and transform from sulfide to sulfate form with formation of watersoluble toxic compounds, which contaminate water sources. The entire Sak-Elga's floodplain is filled with pyrite deposits and is deprived of soil cover. Thus, the small Sak-Elga River receives almost all pollution of smelter and abandoned mines and is the source of secondary pollution.

\section{Conclusion}

Technogenic geochemical anomaly was formed as a result of large-scale copper-smelting production run for almost hundred years without any ecological standards in Karabash region.

Restoration of soil cover that began when the plant was shut down has slowed down after it reopened. Despite the significant reduction of emissions to the atmosphere, they still remain sufficiently high. Concentrations of heavy metals in soils remain extremely 


\section{Concentration, $\mathbf{m g} / \mathbf{k g}$}

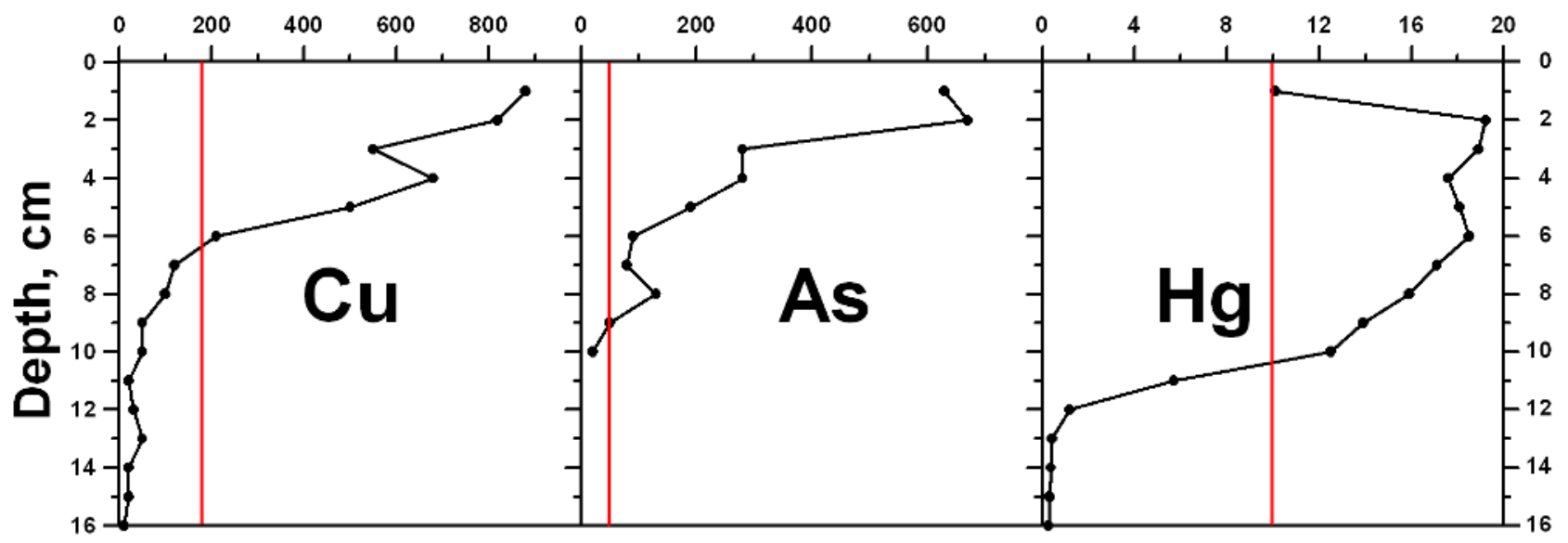

Fig. 2. The distribution of $\mathrm{Cu}, \mathrm{As}$ and $\mathrm{Hg}$ in core of bottom sediments of Lake Serebry

high.

At the same time, the territory of Karabash geotechnogenic anomaly is the natural-technogenic test area, which makes it possible to study degradation and restoration of environment in a changing technological load.

\section{References}

Niemi D. Emissions of Pollutants Related to Acid Deposition in North America. Chapter 2 in 2004
Canadian Acid Deposition Science Assessment, Environ. Canada, Downsview, 2005. P. 5-14.

Richards R.J. Small particles, big problems. Biologist 1997; 44: 249-251.

Udachin V., Williamson B.J., Purvis O.W., Spiro B., Dubbin W., Brooks S., Coste B., Herrington R.J., Mikhailova I. Assessment of environmental impacts of active smelter operations and abandoned mines in Karabash, Ural Mountains of Russia. Sustainable Development 2003; 11: 133-142. 